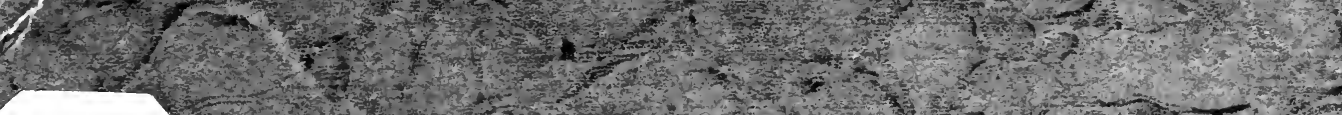

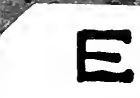

175

.4

.T4

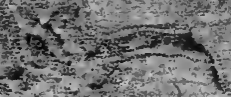

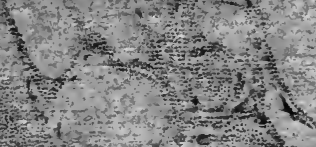

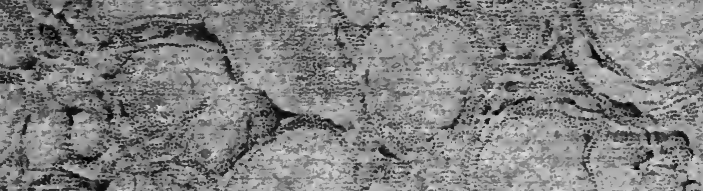

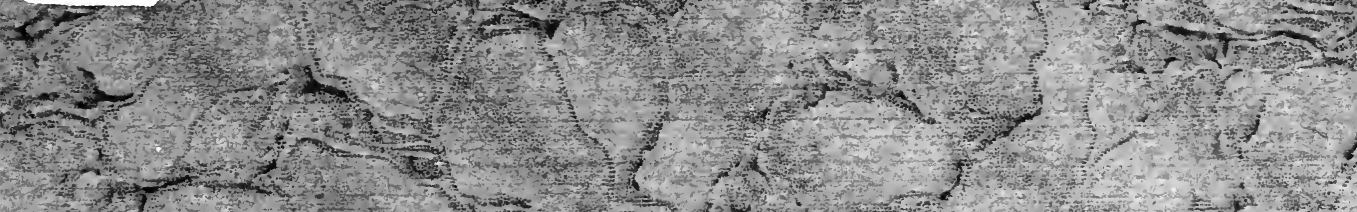

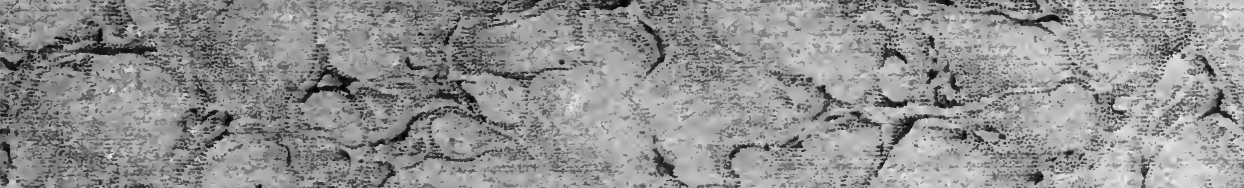

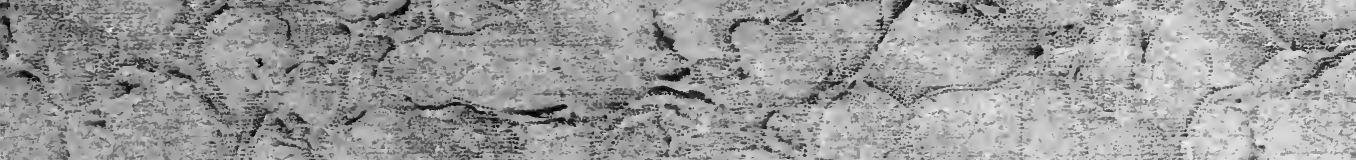

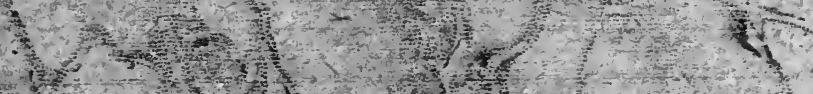

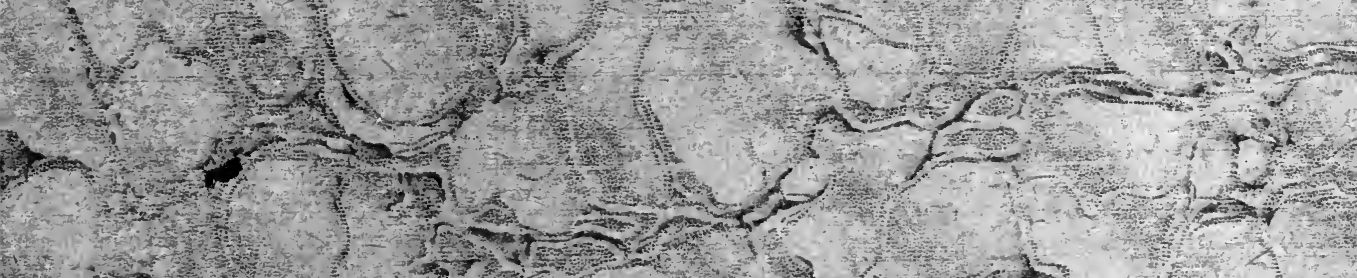

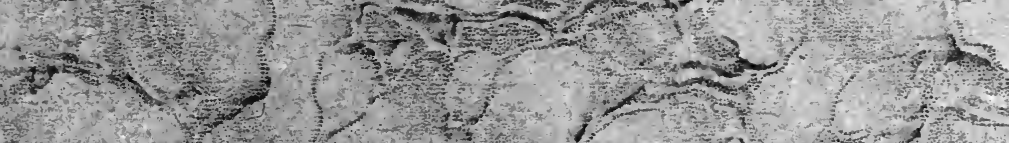

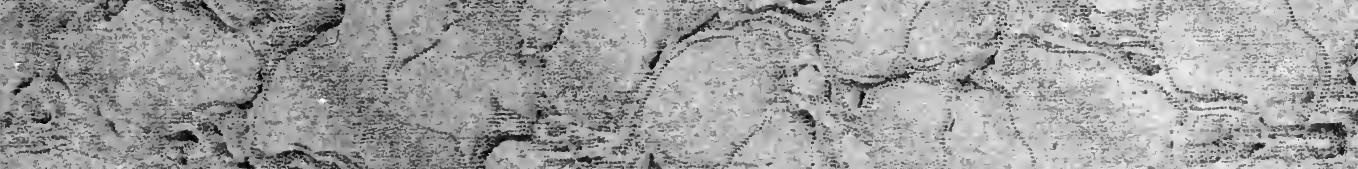

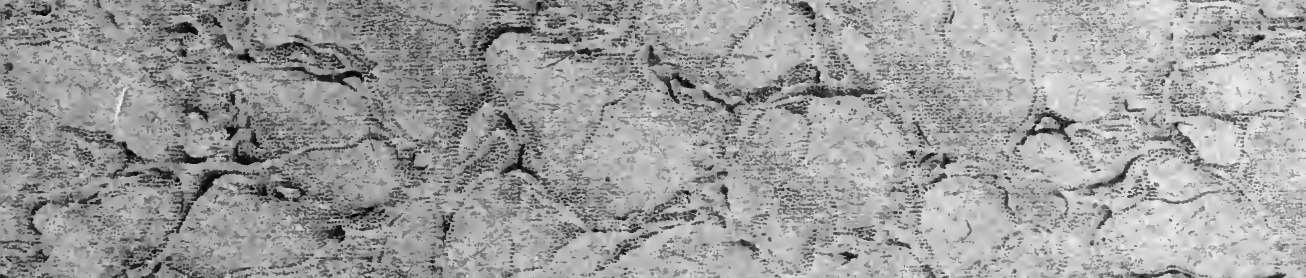

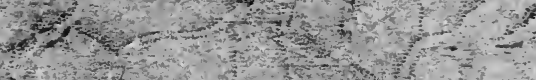

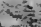

4 $x^{2}$ $\left.\frac{(-1)}{\left(y^{2}\right.}\right)$ (4)

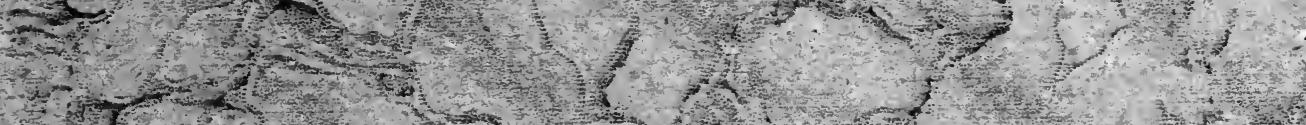

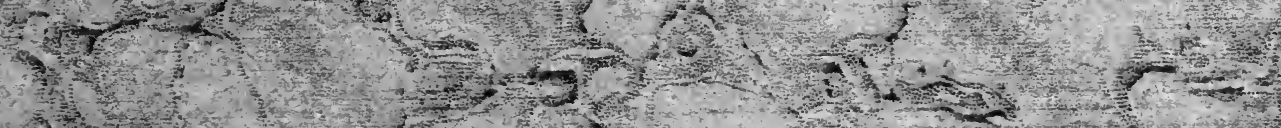
$x+1,4-5,4, a$ 


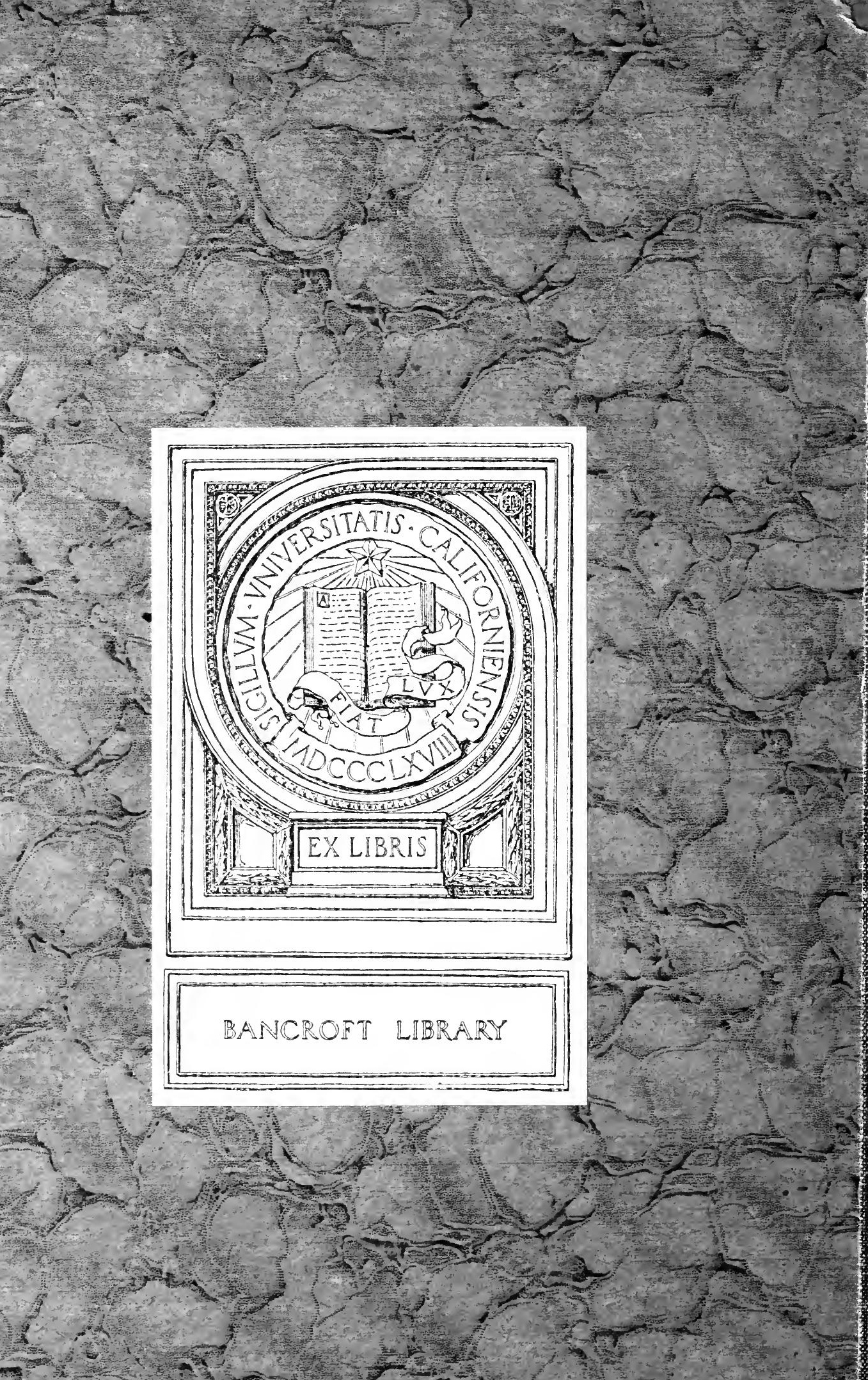



STATE AND LOCAL HISTORICAL SOCIETIES 
$E 175$

.44 


\section{STATE AND LOCAL HISTORICAL SOCIETIES}

At a meeting of the American Historical Association held in Chicago in December, 1904, Professor Henry E. Bourne, of Western Reserve University, and chairman of the Association's general committee, presented a report upon The Work of American Historical Societies. ${ }^{1}$ This was based upon an inquiry conducted by him into the scope and work of the principal societies, and was an interesting and suggestive preliminary survey of the field. As a result of the Bourne report, the Council of the Association appointed Mr. Benj. F. Shambaugh, Mr. Franklin L. Riley, and the undersigned, as a sub-committee of the general committee, charged with reporting at the 1905 meeting upon The Best Methods of Organization and Work on the Part of State and Local Historical Societies.

The task thus assigned was found to be far from a holiday undertaking. As Professor Bourne pointed out: "They [the societies] are as diverse in aim and organization as the localities where they work or the periods when they originated." To attempt to prescribe a set of rules for the com: mon conduct of institutions widely divergent in origin, personelle, purpose, and income was obviously impracticable. The committee, therefore, has been only able to extend and supplement the Bourne inquiry, to present in detail the con-

\footnotetext{
${ }^{1}$ This report appeared in The Iowa Journal of History and Politics for April, 1905, also in the Annual Report of the American Historical Association for 1904, pp. 117-127.
} 
siderable mass of data obtained, and to offer a few practical suggestions based upon this data and the individual observations and experiences of its members.

\section{STATISTICAL}

The committee were convinced that they could not act intelligently without first making as thorough an investigation as possible of the resources, activities, and aims of the historical organizations of the country. A blank was prepared for this purpose, following the general lines of the Bourne inquiry, but much more detailed. This, with an accompanying letter, was mailed early in February, 1905, to the secretaries of societies concerned-the mailing list being compiled from the Bibliography of Historical Societies published by the American Historical Association in 1895, the Carnegie Institution's Handbook of Learned Societies, and other sources.

By agreement between the members, Mr. Riley undertook to secure and compile reports from the societies in the Southern States; Mr. Shambaugh from those of the transMississippi States (except Arkansas, Louisiana, and Texas); and Mr. Thwaites from those of the Northern States east of the Mississippi. The committee held a two days' session at Iowa City, Iowa, May 16-17, 1905, discussed the replies, and arrived at certain conclusions which are presented below.

The majority of the active organizations reported promptly; others required prodding; even to the present date, a few have failed to respond to continued requests. Reluctance to reply has generally been traceable to two widely divergent reasons: serene self-content on the part of conservative and comfortably endowed organizations displaying 
small interest in a coöperative movement of this character; or to indifference bred of hopeless local conditions. In the responses of a few of the older societies was noticeable a tone implying that we had committed an impertinence in thus inquisitively intruding into their placid lives. The net result was the receipt of a body of useful, although quite unequal, data from nineteen national organizations (exclusive of the American Historical Association) having more or less to do with historical work, eight sectional, sixty-one State, and one hundred ten local. While there are regrettable omissions, it may confidently be asserted that practically every important historical society or department in the United States is included in the several lists which have been prepared.

Of the national societies engaged in the collection and publication of historical material-for obvious reasons the American Historical Association is not included-easily the most important in library and resources, is the American. Antiquarian Society. Its substantial building at Worcester, Massachusetts, contains 120,000 volumes and a valuable collection of manuscripts, portraits, and antiques. The American Geographical Society, at New York, is housed in a $\$ 200,000$ building and possesses a library of 40,000 volumes. Other flourishing bodies are the American Numismatic and Archæological Society of New York, the Daughters of the American Revolution (with a large building in Washington, now in process of construction), and the Jewish Publication Society of America.

The list of sectional societies embraces many that are doing important work. The wealthiest and most effective 
of these is the New England Historic Genealogical Society, of Boston, housed in a building worth $\$ 65,000$ and having a library of 66,000 titles. It possesses, also, notable collections of manuscripts, and a large museum of portraits, curios, and antiques. The Confederate Memorial Literary Society, of Richmond, owns a museum and grounds valued at $\$ 60,000$, and an interesting library of printed and manuscript material relating to the history of the South prior to the War of Secession. The Pacific Coast Branch of the American Historical Association, while as yet not engaged in collection or publication, has a promising future as the proposed medium of coöperation between the various historical organizations on the Western coast.

As a class, the State societies and departments were the most punctilious in their replies. Not all of the responses were satisfactory in character; but while there are serious gaps, enough information was elicited to enable the committee to present a fairly complete survey of the situation.

It was found that twelve societies or departments own their own halls - those valued at $\$ 100,000$ or orer being: Wisconsin, $\$ 610,000$; Iowa Department, $\$ 400,000$; Massachusetts, $\$ 225,000$; Pennsylvania, $\$ 200,000$; and New Jersey, $\$ 100,000$. Thirteen are housed in their respective State capitols, seven are quartered in State universities, and six in other public buildings. The largest State appropriations are given to Wisconsin, $\$ 32,000$; Minnesota, $\$ 15$,000; and Iowa, $\$ 15,000 .^{1}$ The Massachusetts, Pennsylvania, and Wisconsin societies are of course the wealthiest

\footnotetext{
1 This includes both the State Historical Society at Iowa City and the Historical Department at Des Moines.
} 
in endowments, possessing respectively $\$ 221,000, \$ 169$,000 , and $\$ 53,000$ in invested funds. The largest libraries are: Wisconsin, 275,000 titles; Pennsylvania, 245,000; Massachusetts, 155,000; Kansas, 115,000; and New Hampshire, 100,000 .

The reports from local societies are unequal, so that doubtless many fairly active small societies are not on our lists; we have reason to believe, however, that nearly all engaged in publication or having libraries or museums are represented. Some of the local societies are institutions of considerable importance. The Essex Institute, of Salem, Massachusetts, with its income of $\$ 15,000$, library of 400 ,000 titles, and building valued at $\$ 28,000$, easily takes rank with the State societies. So also do the New York (City) Historical Society, with 1,057 members, endowment funds aggregating $\$ 236,000$, yearly income of $\$ 12,800$, and a building costing $\$ 400,000$; the Chicago Historical Society, with a library of 100.000 titles housed in a $\$ 185,000$ building, and supported by endowment funds aggregating $\$ 96,-$ 000; the Long Island Historical Society, of Brooklyn, with 70,000 titles in its own building; the Western Reserve, of Cleveland, with 60,000 titles in a $\$ 55,000$ building; the Worcester (Mass.) Society of Antiquities, housing 55,000 titles within a building valued at $\$ 25,000$; and the Buffalo Historical Society, which dwells in a $\$ 200,000$ building, has a library of 16,000 titles, and receives a muricipal grant of $\$ 5,000$ per annum (the only instance of this sort that has come under our notice).

Many of those owning much smaller libraries and museums, quartered in less costly houses, are also institutions wielding 
a wide influence in historical study. It is interesting to note the considerable number finding lodgment in public library buildings, a significant connection promising well for both organizations. In several of the Eastern States, notably in Massachusetts, where nearly every town possesses an historical society as well as a public library, the former frequently owns or rents some historic building, generally a colonial farmhouse which, often with excellent taste, has been converted into a public museum. This is an example well worth following by other local societies. In the South and the Middle West are many communities with historic structures that might be preserved for a like purpose.

ORGANIZATION

Each historical society is in large measure the product of local conditions and opportunities. But back of these, moulding conditions and taking advantage of opportunities, are needed individuals imbued with genuine and self-sacrificing enthusiasm in the cause. However, enthusiasm will not alone suffice; for the promoters of such enterprises should by their erudition and technical skill command the attention and respect of scholars, while by display of practical common sense, business ability, energy, and convincing arguments, they are at the same time winning the confidence of hard-headed men of affairs. Very likely this is an unusual combination of qualities, and an ideal seldom if ever realized, for historical societies can not pay large salaries. Certain it is, however, that even when liberally endowed, no society has attained its full measure of usefulness without some such personality dominating its affairs. Institutions dependent upon State aid are peculiarly in need of this vig- 
orous personal management. The lack of it has been the undoing of a goodly share of the wrecked or moribund societies-wherein everybody's business was nobody's concern - that strew the pathway of our recent investigation.

The Massachusetts and Pennsylvania societies are prototypes of the privately-endowed organizations of the Eastern States, which without official patronage have attained strength and a high degree of usefulness; while Wisconsin, Minnesota, Iowa, and Kansas similarly stand for the Statesupported institutions of the West.

Of recent years, there has appeared in several commonwealths the "State Department of Archives and History." This is an official bureau of the Commonwealth, obtaining the essential personal touch through maintenance of close relations with the State historical society, whose duties, under such conditions, are chiefly literary and advisory. Alabama and Mississippi are the typical examples; put in Iowa the State society, at the seat of the State University, retains a strong individuality in all lines of activity, despite the existence of a liberally-supported historical department at the capital; in Kansas the society has charge of the department.

As to which method is best for new Commonwealthsthat of the Alabama type, that of Wisconsin, that of the Iowa compromise, or that of the Kansas union-your committee will not venture an opinion. Each has certain merits, largely dependent on conditions of environment.

When subsidized as the trustee of the State, the society has the advantage of official connection and support combined with a strong, effective personal interest among its 
widely distributed membership; but there is always a lurking danger of an outbreak of political jealousy of a quasiprivate organization being awarded even the officially-guarded expenditure of public funds, and legislative interference is always possible. While it lacks the inspiration of personal backing, the department stands closer to the machinery of government, and although, under careful laws, removed from liability to partisan control, is not likely in the course of its work to arouse official jealousy. Its greatest danger lies in the possibility that the performance of its work may in time become perfunctory, when the public-spirited founders of the department have retired from service. ${ }^{1}$

After all, the principal desideratum is, as we have indicated, the personality back of the work, rather than the form of organization. It would be unwise, even if possible, to attempt the making over of men or of methods, that in their respective environments either promise or have already attained satisfactory results. What is needed, rather, is the betterment of existing methods, and especially the enlisting in the service of well-trained and vigorous executive officers.

Inspired, doubtless, by the example of the Wisconsin society, which is in close, although not official, connection with the University of Wisconsin, there has recently been a strong tendency on the part of Western and Southern historical agencies to associate themselves with their State uni. versities. At the university town, of all communities in the State, exists a body of scholars who can most profitably utilize the collections of the historical society. The schol-

\footnotetext{
1 See R. G. Thwaites, State-supported Historical Societies and their Functions, in Annual Report of American Historical Association for 1897, pp. 61-71.
} 
ars need the inspiration of persistent, intelligent collection and publication; the society managers need the academic atmosphere and academic counsel in and with which to broaden and solidify their work; while the historical library finds its raison d'être in the largest possible clientêle of users. Recognition of these facts has, wherever possible, led to a closer union between society and university; but in several States, as in Missouri and Washington, where union with existing agencies seemed impracticable to the universities, the latter have secured the organization of rival State societies at their own seats. Such an arrangement, while doubtless benefiting the universities, is apt to result in divided interest and appropriations. In several Western States, difficulties of this character present problems that doubtless will be many years in the solution.

\section{SCOPE AND PURPOSE}

Some historical organizations are founded for a single, well-defined purpose - such as the Society for the History of the Germans in Maryland, the City History Club of New York, and the Germantown Site and Relic Society-these of course find no difficulty in determining their functions. But some of the more general societies, especially in the newer States, appear to be confused in this respect, and queries are frequently raised as to their proper scope.

In the judgment of the committee, an historical society, be it sectional, State, or local, should collect all manner of archæological, anthropological, historical, and genealogical material bearing upon the particular territory which that society seeks to represent. The problem would be simplified, were the ideal recognized that, wherever practicable, there 
should in each State be some one place where all manner of historical data relative to the Commonwealth at large should be placed for preservation and consultation; and in each. community or county a similar treasure house for its purely local records and relics.

It would be superfluous in the present report-which is not intended as an elementary treatise - to set forth in detail the lines of work along which a local historical society may profitably employ itself. But we venture to make these general suggestions: Such an institution may properly make an accurate survey of the archæology and ethnology of its district; not only itself acquiring a collection illustrating the same, but entering into fraternal relations with neighboring collectors, private and public, and perhaps publishing a coöperative check-list. The records of the county government (or of the town, the village, or the city), of the courts, the churches, and the schools should at least be listed if they cannot actually be procured. Diaries of original settlers, mercantile account-books, anniversary sermons, private letters describing early life and manners, field-books of surveyors, etc., are valuable manuscripts worthy of systematic collection. Local newspaper files are an important source of information, and should assiduously be collected and preserved. Pioneers should be "interviewed" by persons themselves conversant with the details of local history. All manner of miscellaneous local printed matter should be secured, such as society, church, and club year-books, programmes of local entertainments, catalogues and memorabilia of educational or other public and private institutions within 
the prescribed field of research-nothing of this sort comes amiss to the historical student. ${ }^{1}$

Collections are naturally classified into libraries, museums, and portrait galleries. Into the library are properly deposited all manner of manuscripts, books, pamphlets, leaflets, broadsides, newspaper files, etc. They should be scientifically catalogued, so far as funds will allow, the manuscripts being if possible calendared, or in any event indexed; the least that can be expected is, that manuscripts be properly listed on standard catalogue cards. In the museum and gallery there should be deposited all portraits or relics bearing on the manners, early life, or personelle of the community or region. Public museums are frequently presented with embarrassing gifts; but tact and diplomacy can usually be depended on for eventual elimination. Perhaps in no department of a society's work are common sense and the trained judgment of the professed historical worker more frequently needed than in the conduct of the museum. This is one of the most valuable features of collection, when properly selected and administered; but unfortunately too many of our American societies are the victims of undiscriminating antiquarianism - collection for collection's sake, without method or definite notion as to the actual scholarly value of the relic. Nothing is more deadly, in historical work, than unmeaning museums of "popular attractions."

In several of our States, the archives of the Commonwealth are, when ceasing to be of immediate value in the ad-

1 Consult the following Bulletins of Information issued by the Wisconsin Historical Society: No. 12, "Suggestions to Local Historians in Wisconsin"; No. 25, "The Gathering of Local History Material, by Public Libraries"; No. 9, "How Local History Material is Preserved." 
ministrative offices-"dead documents," they have somewhat inappropriately been termed-committed to the care of the State historical society or department of history. While eminently desirable, this disposition is, for various reasons, not immediately possible of attainment in every State. The State society or department may, however, properly interest itself in seeing that the archives are conveniently located and carefully preserved by public officials; and where practica. ble, offer expert advice as to their proper administration.

\section{METHODS OF PRESENTATION}

The gathering of material is of basic importance; but much greater skill is required adequately to disseminate that material. So far as practicable, this should be published, in order to secure the widest possible publicity and consequent usefulness.

The publications of historical societies may contain both the original material, or "sources," and the finished product, in the form of monographs, essays, or addresses. State societies should certainly include in their publications everything of value to students to be found in the archives of the Commonwealth; local organizations may with equal profit search their several county and municipal records for all data of historical importance. Bibliographies and checklists of publications relative to State and local history are also desirable.

These publications should be well and attractively printed, on good paper, and as skillfully edited as possible. So far as the canons of scholarship will allow, they should be capable of popular understanding and appreciation. The mass 
of publications by our American societies is large, although by no means as extensive as it properly might be. Unfortunately, neither the dictates of typographical taste nor of scholarship have always been followed, so that we have upon our library shelves devoted to State and local annals much that is inaccurate as to matter, mechanically execrable, and in general slipshod. It is high time that those historical societies sinning in this respect bestir themselves, and inaugurate a more scientific treatment of their otherwise useful material. We have come to the stage that competent editors are needed quite as much as indefatigable collectors.

State or local bibliography is an important and much needed work, that may well be undertaken by historical societies, each in its own class. The example of The State Historical Society of Iowa in inaugurating a monographic industrial history of that State, and a reprint of important State papers, is worthy of emulation. Many local societies are, in our opinion, spending far too largely of their substance in genealogical research and publications. With numerous professed genealogical societies in the field, to say nothing of the often useful patriotic hereditary chapters - too few of which, however, are publishing things worth while-the general historical organization may with more appropriateness devote itself chiefly to the abundant task of putting forth documentary material and monographs bearing upon its field. Any enterprising and skillfully conducted society, once entering upon publication, will find the possibilities in this direction practically endless. Rescroft Liftrary

The methods of distribution of publications should be carefully considered. It is important that material deemed 
worthy of permanent preservation in printed form should be placed where it will be of the greatest possible use to scholars. In our opinion, the Library of Congress should, as the national library, be an early recipient of all such publications; next, the largest and most frequented reference libraries throughout the United States should be selected as natural repositories, whether the publishing society is or is not in regular exchange therewith; exchange arrangements should, as far as possible, be entered into with kindred societies throughout the State and country; naturally, the members of the society and the public libraries of the State and neighborhood will be upon the permanent mailing list. A society that does not thus disseminate its publications where they can do the most good, is in so far neglecting its duty to American historical scholarship.

The museum is also an important, although necessarily limited, means of presentation of material. With tasteful and carefully phrased labels, changing exhibits of books and manuscripts, loan collections, lectures to teachers and pupils of the public schools, bibliographical references, etc., much may here be done to arouse and maintain public interest.

INTERESTING THE PUBLIC

Indeed, this matter of arousing and maintaining public interest is, of itself, an important function of an historical society; but obviously this should be an intelligent, discrim. inating interest. Field meetings, popular lectures, work with the schools, some measure of coördination with the pioneer and old settlers' societies of the district, pilgrimages to places of historic interest, the promotion of anniversary cele- 
brations, and the placing of tablets upon historic sites, all of these are within the province of the society.

The enlistment of college and university interests is likewise highly desirable, especially in the matter of research and preparing material for publications; although in becoming academic the society should be careful not to remove itself too far from the understanding and sympathy of the common people. Popularity and exact scholarship are not incompatible. One of the principal aims of an historical society should be the cultivation among the masses of that civic patriotism which is inevitably the outgrowth of an attractive presentation of local history.

Logically, there is no reason why the work of collecting and disseminating historical material should not be quite as much a public charge as that of the public library or of the public museum. But the fact that historical work appears to be best prosecuted by individual enthusiasm, seems to render essential the society organization; and in many communities it is, as already intimated, difficult to convince legislative assemblies that a semi-private body should receive public aid. This objection is not insuperable, provided there are not, as in some States, likewise constitutional barriers. In the West, arrangements have been entered into whereby the society, in accepting public aid, becomes. the trustee of the Commonwealth, as the custodian of State property; yet in no sense does the society surrender its scholastic individuality. In Buffalo, the local society bears much the same relationship to the municipality, in return for the latter's annual stipend. Even under the most favorable political conditions, however, there is small chance for the: 
historical society obtaining official aid unless its work is winning popular appreciation.

\section{COÖPERATION}

No historical society in the United States, State or local, is so powerful that it may not wax stronger by coöperation with its fellows. Small organizations need the advice, assistance, and inspiration that come from consorting with larger and more experienced bodies; the latter will attain fresh vigor by coming into close touch with institutions nearer to the people.

In Iowa and Wisconsin, coöperation is assured by making the local societies auxiliaries of the State organization. The latter publishes the annual reports of its auxiliaries, and such of those papers produced by members of the local bodies as have the stamp of excellence and are of more than local significance. At meetings of the State body, the auxiliaries are officially represented, and frequent correspondence is encouraged between the parent society and its off'spring; indeed, the local leaders become active members, as well, of the former.

Massachusetts has inaugurated a Bay State Historical League, thus far composed of twenty-one local societies in Middlesex and Essex counties. The organization was formed at Boston, April 3, 1903, its objects being defined as follows:-(1) "To encourage the formation of historical societies; (2) to encourage the existing historical societies in the prosecution of historical study and the dissemination of historical knowledge, in the institution and maintenance of historical memorials and anniversaries, the collection, preser- 
vation, and publication of historical material, znd to bring such societies into a closer relation with one another; and (3) otherwise to promote historical interests."

Annual meetings are held at historic points, with addresses of prominent persons, pilgrimages to places of interest, and informal conferences regarding common interests. It is hoped that by thus combining their forces, the several societies in the league may stimulate popular interest in the history of their region, while leaving each society free to work out its own problems.

The Pennsylvania Federation of Historical Societies, organized at Harrisburg, January 5, 1905, is of State-wide scope, but apparently confined to the local bodies. Its announced purpose is: "(1) To organize historical activity in every part of the state and to foster it, and to foster that already organized. (2) To act as a federation bibliographer for its component societies. (3) At regular intervals, or periods, to bulletin the publications of its component societies, and to conduct an exchange of said bulletins." The State librarian, the Hon. Thomas L. Montgomery, is taking an active interest in the work, and thus far the expenses of the federation appear to have been made a matter of State charge.

Upon the Pacific Coast are several active State historical societies, notably those of Oregon and Washington. The Southwest Society of the Archæological Institute of America, with headquarters at Los Angeles, under the able leadership of Dr. Charles F. Lummis is rapidly coming to the front, and promises soon to become an important factor in historical research in this interesting region, embracing Texas, New Mexico, Arizona, and Southern California. 
The conference of historical societies of the Pacific Coast, conducted at Portland in the third week of August lastand participated in by Messrs. Shambaugh and Thwaites of the American Historical Association committee on historical societies-was a spirited gathering. But the disadvantage arising from the great distances between the several centres of far Western historical activity was strongly expressed, and the need of some central agency of coöperation emphasized, this being the key-note of the discussion. There was a general feeling of satisfaction when it was unanimously determined to utilize the Pacific Coast Branch of the American Historical Association as such common medium. Herein lie large opportunities for the Branch, and it is sincerely hoped that its managers may succeed in realizing the aspirations awakened in the several State societies by this new relationship.

The four several attempts at coöperation above enumerated, are typical and suggestive:-(1) An attempt to coördinate the work of a limited district within a State immensely rich in historical material and opportunities; (2) a federation of the local historical societies of an entire Commonwealth, independent of the State society; (3) a system whereby local societies are admitted as auxiliaries of the State organization; and, (4) a suggestion to effect coöperation throughout a wide belt of historically-related Commonwealths, by utilizing a sectional branch of the American Historical Association.

Still another form of coöperation has, on motion of the Wisconsin society, recently been inaugurated in the region of the upper and central Mississippi Valley. That institution being about to publish a bulletin descriptive of its own 
manuscript collections, proposed to other libraries, societies, and private collectors in its neighborhood, to append thereto similar descriptions of such of their manuscripts as bear upon American history. Favorable responses were received from the Historical and Philosophical Society of Ohio (Cincinnati), the Old Northwest Genealogical Society (Columbus), Mr. C. M. Burton of Detroit, the Chicago Historical Society, the Chicago Public Library, the Newberry Library of Chicago, Mr. Edward E. Ayer of Chicago, the Minnesota Historical Society (St. Paul), the State Historical Society of Iowa (Iowa City), the Missouri Historical Society (St. Louis), the Mercantile Library of St. Louis, the State Historical Society of Missouri (Columbia), and the Kansas Historical Society (Topeka). The publication of these lists of manuscripts under one cover and commonly indexed, will of course prove helpful to students of American history by enabling them to ascertain the strength of nearly all the several collections in the upper Mississippi basin, at the minimum expenditure of time and effort.

It is hoped by the Wisconsin society that this bulletin may prove suggestive to other sections, as an example of one form of possible coöperation. ${ }^{1}$ Similar coöperative bibliographies might well be compiled of portraits, broadsides, and other illustrative matter, and check-lists be prepared of rare historical works, documentary collections, etc. The

\footnotetext{
${ }^{1}$ So long ago as 1897, the Wisconsin society published: I. S. Bradley, "Available Material for the Study of Institutional History of the Old Northwest," Wisconsin Historical Society Proceedings, 1896, pp. 115-143. This consisted of a list of the statutes, session laws, legislative documents and journals, journals of constitutional conventions, and newspaper files of the Old Northwest Territory and of the States of Ohio, Indiana, Illinois, Michigan, and Wisconsin, published prior to 1851 , to be found in public libraries within those States.
} 
example set by the libraries of Boston, Washington, and Chicago, in publishing coöperative lists of their periodicals, may well serve as a hint for the historical societies.

The Library of Congress, acting in conjunction with the Carnegie Institution's Department of Historical Research, has now fairly entered upon its great task of securing transcripts of all documents in European archives illustrative of American history. As soon as this material is available, it would be quite feasible for local societies in any State, or State societies in any section, to join forces in the editing and publication of so much thereof as was considered common to the history of the territory embraced in such federation. A union for the purchase or transcription of such other materials as did not come within the scope of the Washington undertaking might also be established. Even in limited sections, such as that served by the Bay State Historical League, a coöperative bureau would doubtless be found helpful, especially in interesting the public.

In the publication of documentary material, no doubt there has occasionally, in neighboring States, been more or less duplication. There have been instances of duplication between State and local societies within the same Commonwealth, arising from lack of agreement as to their respective fields. Coöperation would tend to minimize this difficulty; yet in the case of State-supported societies there are apt to be certain official barriers to perfect coöperation-and it is open to question whether duplication has not some advantages, for the publications of one State are not as a rule freely obtainable by students in another. It is, however, important that there should be some common understanding 
in these matters, in order that what is done shall be done intelligently and purposely.

Indeed, it is in just such inter-society conference as this, that the most useful coöperation may be effected. Within States, no doubt organized federations like those of Pennsylvania and Massachusetts will best subserve the interests of all concerned, and secure both continuity of united effort and proper differentiation; but between State societies, it is possible that in most cases a hard-and-fast organization might prove less useful than temporary conventions to meet immediate and varying needs.

Another form of coöperative agreement is essential between historical societies and public libraries working within the same field. As already noted, many local societies are quartered in the buildings of such libraries, the former being granted either a separate library and museum room, or special alcoves in the book-stack. Differentiation is thus easily arranged, and each institution can be and often is of great benefit to the other. But there are numerous instances where society and public library are engaged in needless and costly duplication. In such cases, some sort of affiliation should certainly be entered into.

The relations between State historical societies and State libraries are likewise often quite lacking in definition. Differentiation is simple in those Western States, like Wisconsin, where the State society, acting as the trustee of the Commonwealth, conducts what is in effect the miscellaneous State library, the nominal State library being simply the law library of the Supreme Court. But this condition obtains in but few Commonwealths; in others, agreements 
have yet to be perfected, by which these two agencies of collection shall supplement each other rather than duplicate.

A system of annual reports from local to State societies, would be desirable, as in the case of the auxiliaries in Iowa and Wisconsin. On the other hand, similar reports from State organizations to the American Historical Association, although not provided for in the latter's charter, would surely tend to arouse more general interest in an undertaking in which all are deeply concerned. At present, the work of the societies is too largely individual and to that extent narrow; it sorely needs unifying, sectionally and na tionally. Federated relationship, organized or unorganized would, in our opinion, strengthen the hands of all, from the national body to that of the smallest historical society in the land.

Until the "round table" conference at Chicago, in 1904, several of the most important of the State societies were quite unrepresented at the sessions of the American Historical Association. Very likely this has been the fault of the Association quite as much as theirs; for in the former's programmes scant attention has hitherto been paid to the serious problems confronting State and local societies-support, organization, scope, methods, and co-öperation. The Council of the American Historical Association has, however wisely created a section devoted to these matters, and its successive annual conferences will doubtless bear rich fruitage.

Reuben Gold Thwaites

Wisconsin Historical Society

Madison 




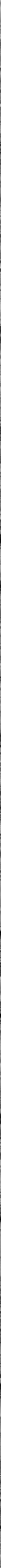

